\title{
Analítica da linguagem radiofônica: um novo olhar sobre o rádio
}

////////////////I// Rafael Duarte Oliveira Venancio ${ }^{1}$

1. Doutor em meios e processos audiovisuais pela Escola de Comunicações e Artes da Universidade de São Paulo. É coordenador e professor dos cursos de rádio, TV e vídeo, produção audiovisual e produção multimídia da FMU-FIAM-FAAM, além de professor da graduação e da pós-graduação lato sensu do Centro Universitário Senac. E-mail: rdovenancio@gmail.com 


\section{Resumo}

O presente trabalho visa entender como o rádio se distingue dos demais sons do mundo. A hipótese aqui formulada é a de que o rádio, em sua definição, é uma linguagem, e não um aparelho. Com isso, há um estudo detalhado do rádio em seu jogo de linguagem e em seus diferendos, considerados aqui enquanto parergon e ergon, ou seja, enquanto recorte e modelo operacional da linguagem em sua intersecção com o mundo. Essas duas investigações formam aquilo que é chamado aqui de gramática do rádio, o ponto nodal que nos permite caracterizar o rádio enquanto linguagem.

\section{Palavras-chave}

Rádio, linguagem midiática, filosofia analítica da linguagem.

Abstract

The present work aims to understand how the radio distinguishes itself from other sounds of the world. The hypothesis formulated here is that the radio, in its definition, is a language, not a machine. Here, there is a detailed study of the radio in its language-game and their differends, considered in this work as parergon and ergon, i.e., as the cut and the operational model of language in its intersection with the world. These two studies form what is called here the radio grammar, the key point that allows us to characterize the radio as a language.

\section{Keywords}

Radio, media language, analytic philosophy of language. 
O questionamento acerca do que é determinada prática midiática é um dos desafios postos desde os primórdios das pesquisas no campo da comunicação social. Essa busca por existenciais - pela resposta do intrigante "O que é" - sempre foi vista enquanto grau máximo de afirmação de um determinado meio.

Para exemplificar usando a prática midiática que é alvo do presente trabalho, a busca pelo "O que é o rádio?" sempre esteve envolta em uma afirmação do meio, tal como se a resposta pudesse apenas ser dada por uma visão aparelho-centrista, ou seja, pelo meio (i.e., o rádio-receptor AM-FM, por exemplo), e não pela prática (i.e., o fazer radiofônico).

Ora, será que esse é o melhor caminho de definição? Será que "O que é o rádio?" é simplesmente aquilo que é transmitido e recebido pelo aparelho? Há muitas situações que demonstram o contrário, e o curioso delas é que, normalmente, elas são postas no exterior da prática midiática radiofônica.

São os casos das imitações da fala radiofônica por humoristas e por professores em seu trabalho didático, das representações da fala radiofônica em outras práticas midiáticas (por exemplo, a narração radiofônica no filme O bandido da luz vermelha) e, até mesmo, dos meios digitais sonoros que soam tal como rádio sem utilizarem o aparelho de rádio (i.e., podcasts, audio streamings).

Com isso, podemos observar a autonomia da linguagem radiofônica em relação ao aparelho, que, no limite, é o que proporciona o seu status de linguagem. O que move a prática radiofônica não 
2. Tractatus é WITTGENSTEIN, 2009, Investigações filosóficas é WITTGENSTEIN, 1999 e Zettel é WITTGENSTEIN, 1989. No entanto, para manter a normatividade dos estudos da área, utilizaremos a citação via proposições ou parágrafos. Ex: (TLP 5.6), (IF, 『528) e (Z, \$327). Isso também será feito com Le différend (LYOTARD, 2007), que também é dividido em parágrafos proposicionais. são mecanismos de transmissão e recepção mecânicos, mas sim seu caráter de linguagem, suas possibilidades de recorte do mundo proporcionadas pela concatenação e pela especificação.

Claramente, a linguagem radiofônica permite um recorte do mundo, até porque, dada sua capacidade linguística, ela é recorte em duas maneiras: (1) ela proporciona uma ordem das coisas; e (2) ela mesma é recortada do mundo, ou seja, dos demais sons. Essas duas maneiras são as duas faces de um mesmo recorte, sendo indissociáveis. Suas condições de existência e de (re)presentação consistem nesse mecanismo linguístico.

Ora, basta pensarmos na proposição 5.6 do Tractatus logicophilosophicus ${ }^{2}$, uma das mais conhecidas frases do livro de Ludwig Wittgenstein: "Os limites da minha linguagem significam os limites do meu mundo” (TLP 5.6). De função essencial dentro da chamada teoria pictória do primeiro Wittgenstein, essa frase também animou diversos estudos dentro do campo das ciências da linguagem.

A ela, normalmente, se adiciona uma outra proposição do Tractatus, a 4.015: “A possibilidade de todas as símiles, de todas as imagens [imagery] de nossa linguagem, reside na lógica da representação". Para muitos, essas duas proposições mostram a conexão entre as obras das duas fases wittgensteinianas: a do Tractatus e a das Investigações filosóficas. No entanto, o foco pretendido por este trabalho não é entrar no debate acerca do caráter terapêutico que Wittgenstein pode ou não pode ter. Tal como ficou claro pelas duas proposições wittgensteinianas selecionadas, o objetivo é a questão da representação dentro de um domínio da linguagem.

E aqui somos tributários das Investigações filosóficas, que, tal como bem diz Gomes (2001), colocam a questão da representação do mundo - de certa forma, dentro da totalidade proposta por TLP 4.015 e 5.6 - enquanto apresentação do mundo. Há aqui uma questão que vincula essas duas palavras por causa de sua diferença prefixal: "Representação constitui esse ato substitutivo, incluso no 're', que nos remete a uma rememoração enquanto apresentação nos fala do mundo colocado pelo ato de significá-lo" (GOMES, 2001, p. 36). Isso é uma referência a uma importante passagem das 
Investigações filosóficas, a do \$397. Por isso, tal como já utilizamos esse termo alguns parágrafos antes, há uma (re)presentação, abarcando esse jogo de apresentar-representar no mundo. Aqui vale a pena retomar o escopo do $\$ 397$ dentro dessa obra de Wittgenstein. Baker e Hacker (2005), por exemplo, consideram esse parágrafo enquanto fronteira entre duas seções de pensamento descritas no livro. É uma conclusão dos estudos de Wittgenstein acerca da imaginação e um gatilho para o início da seção de sua investigação acerca do Vorstellungwelt, o mundo das representações.

Devemos, então, citar o parágrafo para qual o \$397 prepara o terreno reflexivo.

"Mas quando represento algo para mim, ou também quando vejo realmente objetos, então tenho algo que meu próximo não tem." - Compreendo-o. Você quer olhar em torno de si e dizer: "Apenas eu tenho ISSO." - Para que essas palavras? Não servem para nada. Sim, não se pode dizer também que "não se trata aqui de um 'ver' - e, portanto, também de um 'ter' - de um sujeito, e também de um eu”? Não poderia perguntar: aquilo de que você fala, e diz que apenas você o tem, em que medida você o tem? Você o possui? Você nem sequer o vê. Sim, você não deveria dizer que ninguém o tem? É também claro: quando você exclui logicamente que um outro tem algo, também perde o sentido dizer que você o tem.

Mas, então, do que é que você fala? Na verdade, disse que sei, no meu íntimo, o que você tem em mente (meinst). Mas isto significaria: eu sei como se tem em mente conceber e ver esse objeto, como se tem em mente, por assim dizer, designá-lo por meio do olhar e de gestos. Sei, neste caso, de que modo olha-se em frente e em torno de si - e outras coisas. Creio que se pode dizer: você fala (quando você, por exemplo, está sentado no quarto) de um "quarto visual". Aquilo que não tem possuidor é o "quarto visual”. Não posso possuílo assim como não posso andar nele, olhá-lo ou mostrá-lo. Não me pertence, na medida em que não pertence a nenhum outro. Ou: não me pertence, na medida em que empregaria para ele a mesma forma de expressão que emprego para o quarto material, no qual estou sentado. A descrição do último 
não precisa mencionar nenhum possuidor, não precisa mesmo ter nenhum possuidor. Mas, então, o quarto visual pode não ter nenhum. "Pois não tem outro senhor senão ele e nenhum nele” - poder-se-ia dizer.

Imagine uma figura de paisagem, uma paisagem de fantasia, com uma casa - e que alguém perguntasse: “A quem pertence a casa?" - A resposta poderia ser: "Ao camponês que está sentado no banco em frente dela”. Mas este não pode, por exemplo, entrar em sua casa (IF, \$398).

Postos aqui o \$397 e o \$398, é necessário descrever os dois movimentos explicitados por eles nas Investigações filosóficas. O primeiro parágrafo, o da (re)presentação, demonstra uma questão interessante nesse ponto do pensamento de Wittgenstein. É o momento no qual o autor deixa clara a natureza da linguagem enquanto (re)presentação. Isso é da ordem do gramático, da lógica dos jogos de linguagem aos quais somos submetidos. É errôneo achar que, por exemplo, a imaginação delimita as fronteiras do sentido, podendo até expandi-lo. Na realidade, a "imaginabilidade" está entre os critérios lógicos já postos. Tal "gramática não é um 'grande espelho'. Ela não reflete a essência das coisas. Ao contrário, ela é autônoma. Ela determina a essência das coisas" (BAKER; HACKER, 2005, p. 19).

Mas não podemos acreditar, tal como bem nos coloca o $\$ 398$, que essa gramática é apenas mais uma forma de Vorstellungwelt. O que há de importante para notar aqui é que estamos postos na linguagem, imersos em seus jogos, e que tudo, na verdade, é (re)presentação, não só por sua falta de autonomia, mas porque tudo são utterances da lógica do mundo. Não somos donos do quarto visual, nem do Vorstellungwelt, somos parte dele. Assim, a (re)presentação da linguagem radiofônica é sua capacidade de ordenação e de apresentação. Seja falando dela ou falando através dela, ressaltaremos esse recorte, o locus de sua definição linguística. Mas como podemos caracterizar o rádio enquanto linguagem? 


\section{Parergon/ergon, jogo de linguagem/diferendo: métodos linguísticos e o rádio}

Assim, a postura do presente trabalho é tratar o rádio enquanto um jogo de linguagem, sendo possível traçar uma gramática. É através dela que podemos caracterizar o rádio enquanto uma linguagem. Essa gramática do rádio, baseada no conceito de Wittgenstein, é composta por uma dimensão de escritura - para usar o termo desconstrucionista - que a faz agregar dois dos três setores linguísticos do rádio, representados pelo quadro esquemático a seguir:

\begin{tabular}{|l|l|l|}
\hline \multicolumn{1}{|c|}{ parergon } & \multicolumn{1}{|c|}{ ergon } & \multicolumn{1}{c|}{ múltiplos } \\
\hline \multirow{4}{*}{ - Jogos de linguagem } & • Diferendo & • Reprodutibilidade técnica \\
- Regras lógicas & • Atos de fala, apostas linguísticas & • Materialidade sonora \\
- Nomas linguísticas & • Estratégias performativas & • Fenômeno \\
- O rádio (o que os une) & • O modelo de programa de rádio & • O programa de rádio em \\
& (o que os distigue) & si (o que se manifesta) \\
\hline Gramática da linguagem radiofônica (ou gramática do rádio) & \\
\hline
\end{tabular}

Aqui, há um uso proeminente dos termos parergon e ergon, retirados da paraestética derridariana. Ora, assim, é a escritura, esse B' da linguagem radiofônica, que proporciona o recorte. Ela é a instância definidora da prática midiática radiofônica e de sua instância linguística.

Esse B' da linguagem radiofônica, seguindo o arcabouço teórico de Jacques Derrida, reside naquilo que é denominado parergon. O conceito de parergon ganha destaque na estética com a Crítica do juízo. Kant (2005, p. 45) constata que os ornamentos (parerga), tal como as molduras de uma pintura, apesar de não fazerem parte da representação artística e, até mesmo, prejudicarem o belo genuíno, são essenciais para uma ampliação e para um reconhecimento do gosto estético.

Essa consideração de Kant - que poderia, até mesmo, passar desapercebida - é retomada por Jacques Derrida em seus estudos de estética. Neles, Derrida afirma que o parergon de uma obra de 
arte indica uma necessidade, uma falta, que ela possui em seu processo representacional. O que constitui os parerga, no raciocínio de Derrida (1987, p. 59-60) "não é apenas a sua exterioridade enquanto um acréscimo, mas sim a ligação interna estrutural que os fixam na falta interior da obra (ergon). E essa falta é constitutiva da própria unidade do ergon. Sem essa falta, o ergon não precisaria de parergon. A falta do ergon é a falta de um paregon”.

Dessa forma, esses ornamentos - tal como a moldura para uma pintura ou uma coluna para um busto - é o que fazem a obra de arte ser reconhecida enquanto tal. É a última fronteira entre o que é e o que não é. Dessa forma, pensando no amplo escopo teórico de Derrida, vemos o quanto o parergon está relacionado com a escritura e com o projeto de desconstrução de antagonismos binários.

Derrida também acredita em um trabalho, ao menos especulativo, em cima do parergon. Especulativo porque podemos vê-lo, conceituá-lo; no entanto, ele é indissociável do ergon. Isso é exemplificado por Derrida (1981) através de um texto de Mallarmé intitulado Mimique, em que a própria imitação do nada é imitação, mesmo se caracterizarmos que para haver imitação é necessário imitar algo.

Essa referência sem referente é o puro trabalho na moldura, a possibilidade aberta pelo parergon que traz para a arte a mesma possibilidade que a archi-escritura traz para a linguagem. "Em um espaço constantemente diferido há uma escritura que funda a fala e a escrita. Fala e escrita, então, supõe uma archi-escritura como condição de possibilidade de toda a linguagem" (FERRO, 1992, p. 102). Se a archi-escritura é a possibilidade de toda a linguagem, o parergon é a possibilidade da linguagem de uma prática estética. Mas o que compõe o parergon e o ergon de uma linguagem, no nosso caso, da linguagem radiofônica?

Ora, a análise do parergon apenas pela letra de Derrida é insuficiente para analisar o nosso trabalho dentro de uma postura derivada da filosofia analítica da linguagem. O que temos, com Derrida, pode ser resumido nos seguintes termos: (1) O parergon é um lugar de (re)presentação, ou seja, é através dele que 
reconhecemos uma prática enquanto tal. Essa (re)presentação opera através de um recorte, uma distinção entre a obra de arte e as demais coisas do mundo; (2) O parergon é uma "função da função". A definição da obra de arte proporcionada pelo parergon não é a demonstração de uma origem (tal como demonstra a tradição representada por Heidegger) ou de uma estrutura. Ela está encerrada em uma função. O parergon nada mais é que uma função que define essa função; (3) O parergon possibilita um trabalho na moldura. Usando a reflexão de Mallarmé, Derrida refletiu acerca das possibilidades de imitação. Imitação e definição de uma obra de arte estão intimamente ligadas; e (4) O parergon indica uma lógica que o relaciona com o ergon. Derrida chama essa situação de uma "violência do emoldurar".

No entanto, o parergon derridariano tende a cair em uma situação ontológica da economia mimética. Ele não ressaltaria o caráter lógico da linguagem do rádio, colocando-o apenas enquanto uma sensação de representação. Assim, há a necessidade de retomar a questão da estética como um jogo funcional de linguagem.

Ao analisar a questão da estética da filosofia desde Hegel até os antiessencialistas, os teóricos analíticos da arte, encontramos mais nove pontos interessantes: (1) A ideia hegeliana de um jogo formal, raiz de entendimento da obra de arte; (2) A presença de um agonismo da linguagem, uma contenda na definição da obra de arte tal como demonstram Schopenhauer e Nietzsche; (3) A importância da combinatória, descrita por Deleuze, para a definição dos jogos que recortam a (re)presentação. A influência da ideia leibniziana de um xadrez no cerne de qualquer representação; (4) A investigação deleuziana da linguagem através de regras de um jogo de significações e sentidos; (5) A questão de uma ausência de criação na arte. Campo artístico como campo de potencialidades e combinações tal como demonstra o debate Kandinsky/Duchamp; (6) A definição do que é arte ou não através da questão de uma álgebra de função tal como mostra Duchamp na questão do readymade; (7) A ausência de essência no recorte da arte diante das coisas do mundo tal como descrevem os antiessencialistas; (8) A analogia entre arte e jogos na questão de suas regras. Essa 
analogia traçada pelos antiessencialistas, baseados na reflexão feita pelas Investigações filosóficas de Wittgenstein; e (9) Por último, a definição das regras do que é ou não uma arte, através do conceito wittgensteiniano de seu ar familiar [Familienähnlichkeit], tal como pregam os antiessencialistas.

Essas nove considerações, somadas com as quatro derridarianas, atualizam o conceito de parergon na medida em que dão para essa condição de recorte um caráter linguístico. Ou seja, não só ele poderá servir para questões de práticas de linguagem, mas no próprio conceito reside um mecanismo com tais propriedades.

Além disso, podemos verificar, através do estudo dos grandes trabalhos anteriores em estética radiofônica, que há uma necessidade: se queremos buscar a autonomia do rádio enquanto linguagem, buscar a sua definição, aquilo que o distingue dos demais sons do mundo, precisamos sair da estética. Há necessidade de ver o propósito radiofônico enquanto necessidade lógica.

Assim, precisamos sair da estética do rádio para partir para algo que condiz com aquilo que vimos com os antiessencialistas, bem como com o arcabouço teórico da filosofía analítica da linguagem aqui proposto. Há a necessidade de ver o rádio - seja nos posicionamentos informacionais, seja na questão "sensória” ou mesmo em seu caráter mais "artístico" - diante do escopo de uma analítica do rádio.

Vemos assim que o parergon, na realidade, é o local de um recorte lógico, que pode ser visto através de mecanismos próprios da linguagem tal como a combinatória. Aliás, na verdade, acabamos por ver que o parergon pode ser visto enquanto locus do jogo de linguagem. É através de um jogo de linguagem que opera a definição de uma determinada prática.

Ou seja, a análise do parergon do rádio é uma análise do jogo de linguagem do rádio. O que faz o rádio se recortar dos demais sons do mundo é o seu jogo de linguagem, o engendramento de regras que se relacionam entre si através de similaridades.

Já o ergon, na dimensão teórica posta pelo presente trabalho, se vincula com a ideia do diferendo. Ora, o ergon, como 
vimos anteriormente, não pode ser considerado a obra em si, mas sim um modelo de obra. Esse modelo de obra é definido pelo diferendo, conceito lyotardiano, determinado como uma estratégia de jogar o jogo de linguagem. Para Lyotard, o que seria a aposta, o lance do diferendo?

Nessa visão, os atores de uma prática artística e/ou midiática (ou qualquer outra atividade (re)presentacional) não fazem as regras dos jogos; apenas podem atuar nelas. E tal atuação é jogando sob a forma de apostas, tal como em um jogo de cartas em que jogar e apostar estão interconectados."Quando Cézanne usa seu pincel, o que está em aposta na pintura é posto em questão; quando Schönberg senta em seu piano, é o que está em aposta na música; quando Joyce pega sua caneta, é o que está em aposta na literatura” (LD, \$192). Dessa forma, mesmo os movimentos mais radicais nos campos artísticos são estratégias de jogar dentro deles. Não há criação; apenas disputa sem consenso, fruto do agonismo da linguagem.

O que são formados aqui são o que Lyotard chama de gêneros do discurso, tal como pode ser visto na citação do $\$ 188$ de Le differénd. Cada escola de estilo é um gênero do discurso, uma estratégia de tentar jogar bem o jogo de linguagem. Há o jogar bem e há o jogar mal, tal como bem notado na visão lyotardiana da letra wittgensteiniana:

Tal como Wittgenstein observa, o conjunto de regras constituindo um jogo de tênis ou de xadrez é uma coisa, o conjunto de recomendações de uma estratégia para vencer é outra coisa. Ignorando o último, você pode jogar "mal”. Mas é ok jogar "mal": "Eu sei, eu estou jogando mal e não quero jogar melhor”. Nesse caso, tudo que o meu interlocutor pode dizer é "Ah, está tudo bem” ([Retirado de] Wittgenstein [Aulas de ética] 1929-1930). Sem mencionar que jogar "mal” pode ser uma boa estratégia, uma sem antecedentes, que no prosseguimento poderá ser dita enquanto “bem jogada!”. Gêneros do discurso são estratégias - de ninguém (LD, \$ 185). 
Assim, o rádio possui um jogo de linguagem, mas o fazer do rádio é um diferendo. Já os programas de rádio em si são apenas múltiplos. Esses múltiplos, meros objetos, são os produtos da gramática do rádio, que, por sua vez, é o amplo escopo interacional entre jogos de linguagem e diferendos, entre regras e maneiras de jogar (de fazer seu lance).

Recapitulando, para mostrarmos o rádio enquanto linguagem, precisamos construir sua gramática, que é composta pela análise do parergon e do ergon. Ora, nosso caminho de reflexão nos levou a constatar que a análise do parergon do rádio é a análise do jogo de linguagem radiofônico e a análise do ergon do rádio é a análise dos diferendos, dos gêneros do discurso radiofônicos. Mas como devemos analisar jogos de linguagem e diferendos?

Para analisar o jogo de linguagem, o presente trabalho desenvolveu uma metodologia denominada jogo lógico, que utiliza o arcabouço da teoria dos jogos, da filosofia analítica da linguagem e da lógica algébrica. Sua estrutura básica é composta por: protocolo de linguagem, jogadores, matriz de jogo e payoffs.

A questão do protocolo de linguagem é o cerne do jogo de linguagem. O jogo lógico serve enquanto método de análise para uma multitude, mas não para a totalidade, dos jogos de linguagem. Assim, fica a questão: quais jogos de linguagem representam essa multitude?

Para iniciar a resposta a essa pergunta, devemos aceitar uma provocação de Ludwig Wittgenstein apresentada no Zettel: "Compara: inventar um jogo - inventar uma língua - inventar uma máquina” (Z, \$327). Esse parágrafo entra, com profundidade, no amplo debate presente na filosofia da linguagem entre as línguas naturais e as línguas formais.

Nesse debate, que contrapõe a linguagem humana à “maquínica”, Wittgenstein provoca ao colocar a terceira questão: o inventar o jogo. É interessante que, no Zettel, encontramos o início da formulação acerca do jogo de linguagem, e a presença de tal afirmação antecipa a pluralidade de jogos de linguagem descritos pelas Investigações filosóficas. 
Dessa forma, há uma série de protocolos de linguagem que fogem da concepção tradicional de línguas naturais e línguas formais. Veja, por exemplo, a questão do "representar teatro". Representar teatro é um exercício de mise-en-scène, de performance, que vai além do uso da língua natural, e não estamos falando aqui apenas do caso das peças de teatro que usam somente expressão corporal. Qualquer peça de teatro possui seu protocolo próprio para ser reconhecido enquanto atividade teatral (e eis aqui a raiz da resposta da questão "O que é o teatro?" ou, pelo menos "O que é a linguagem teatral?").

Assim, vemos claramente que o todo linguístico não é formado apenas por aquilo que poderíamos chamar de línguas mas também por esses protocolos de linguagem. E o jogo de linguagem, nada mais nada menos, é a unidade estrutural que faz tais atividades constituírem aquilo que podemos chamar de linguagem. Sendo que a linguagem é os satzsysteme, a própria "mistura heterogênea" dos jogos de linguagem.

Eis aqui a questão wittgensteiniana dos satzsysteme. Para Shanker, os satzsysteme é a resposta de Wittgenstein para o problema apontado por Ramsey no Tractatus. Ora, nesse livro, Wittgenstein, segundo o seu colega de Cambridge, acaba, ao tentar provar a necessidade lógica através do problema da exclusão de cores, por minar a própria necessidade lógica ao traçar uma conclusão que poderia ser facilmente respondida por necessidades metafísicas (tempo, espaço, matéria, éter). Assim, a forma lógica do Tractatus seria paradoxal, impedindo sua função de separação entre verdade lógica e verdade empírica. A solução - que é o começo do verdadeiro ponto de virada wittgensteiniano para Shanker - é bastante refinada:

Para consertar esse defeito, Wittgenstein introduziu duas grandes inovações, que ele acreditava que poderia possibilitar a resolução do problema da exclusão de cores de tal maneira que iria preservar a demarcação rígida do Tractatus entre verdade lógica e verdade empírica. Seu primeiro passo foi abandonar o modelo abrangente do Tractatus de um único anamórfico cálculo subjacente à língua natural para mudar para aquilo que ele descreve 
enquanto uma concepção de satzsysteme, no qual a linguagem deveria ser vista enquanto uma rede complexa de cálculos interconectados: "sistemas proposicionais" autônomos, sendo cada um capaz de constituir um “espaço lógico” distinto (SHANKER, 1987, p. 6-7).

Esses espaços lógicos construídos pelos sistemas proposicionais [satzsysteme] são nada mais nada menos que os jogos de linguagem: "microcosmos artificiais de linguagem cuja única função é esclarecer vários aspectos da prática linguística de fato” (SHANKER, 1987, p. 9). Assim, "para um dado campo lógico [beweissystem], cada satzsystem pode ser formalizado como a teoria que define a ontologia de um assunto estrito. A multiplicidade de satzsysteme implica que qualquer palavra que é usada em mais de um sistema terá um sentido diferente em cada um” (SOWA, 2010, p. 15).

Dessa forma, podemos entender a provocação do parágrafo 327 do Zettel: as línguas naturais e as línguas formais são beweissysteme no qual os protocolos de linguagem agem. Para entender tais protocolos - especialmente no caráter de sua definição, em seu "O que é", ou seja, sua ontologia - é necessário desenhar espaços lógicos do seu sistema de proposições [satzsystem], que são os jogos de linguagem. Caracterizando a língua natural e a língua formal enquanto beweissystem, nos resta agora analisar e categorizar as diversas línguas-jogos (ou linguagens-jogos). Pensando naquelas descritas pelo parágrafo 23 das Investigações filosóficas, podemos propor a seguinte divisão: (1) Assertórias: Comandar, e agir segundo comandos; Expor uma hipótese e prová-la; Resolver um exemplo de cálculo aplicado; Apresentar os resultados de um experimento por meio de tabelas e diagramas; (2) Comunicacionais: Descrever um objeto conforme a aparência ou conforme medidas; Produzir um objeto segundo uma descrição (desenho); Relatar um acontecimento; Inventar uma história, ler; Representar teatro; Cantar uma cantiga de roda; Fazer uma anedota, contar; e (3) Reflexivas: Conjeturar sobre o acontecimento; Resolver enigmas; Traduzir de uma língua para outra; Pedir, agradecer, maldizer, saudar, orar. 
As assertórias e as reflexivas são procedimentos e usos da língua. São aquelas que operam, muitas vezes, dentro do beweissystem. Já as comunicacionais são aquelas que utilizam um dado beweissystem para criar protocolos autônomos. Basta ver o caso já analisado da linguagem do teatro, que é visto enquanto uma linguagem autônoma, não importando qual campo lógico ele usa (do português, da linguagem de sinais ou mesmo na programação de uma máquina).

Acreditamos que o método do jogo lógico serve especialmente para as linguagens-jogos comunicacionais. Assim caracterizamos o objeto de nosso estudo - o rádio - e a nossa pergunta motivadora - "O que é rádio" ou "Como a linguagem radiofônica se distingue dos demais sons do mundo" - enquanto parte de um jogo de linguagem, de um satzsystem, comunicacional.

É interessante notar aqui que comunicacional não é o mesmo que midiático. O rádio é midiático e comunicacional. Toda linguagem midiática é comunicacional, mas nem toda linguagem comunicacional é midiática. Assim, o satzsystem comunicacional é bastante amplo e caracterizado por esses protocolos autônomos de linguagem que se definem, no limite, enquanto práxis linguística.

Definido o protocolo de linguagem, há a descrição dos jogadores. Há três tipos de jogador para o jogo lógico, baseados na lógica booleana e nos diagramas de Venn: (1) Jogador "letra sentencial": é aquele que participa da lógica do protocolo de linguagem envolvido. Sua quantidade é de dois ou mais por jogo. Possui duas escolhas: existir ou não; (2) Jogador "função de verdade": é aquele que opera a lógica entre as letras sentenciais. No jogo lógico, só pode existir um jogador "função de verdade", cujo número de escolhas estará relacionado com o número de jogadores "letra sentencial" e suas possibilidades numéricas de combinação dual. Esse número de escolhas é o número de funções de verdade possíveis em um dado jogo de linguagem; e (3) Jogador gatilho V/F: é aquele que determina a existência ou não do jogador "função de verdade". No jogo lógico, só pode existir um jogador gatilho V/F, que possui duas escolhas: existência da função ou não. Sendo um jogador com veto, para um jogo de linguagem operar, ele precisa 
escolher pela existência. Caso contrário, o jogo de linguagem não opera, entrando nos vazios da heterogenia do satzsystem.

Dessa forma, fica definido que o jogo lógico, sob o arcabouço teórico da teoria dos jogos, é um jogo de quatro ou mais jogadores. É um jogo à maneira do jogo simples, com lógica bivalente, e um jogo fraco, pois possui um jogador com veto. Além disso, é um jogo em que todos vencem ou todos perdem (ou todos caem em uma impossibilidade). Tendo os jogadores e o escopo linguístico definidos, podemos avançar para o jogo lógico em si, representado pela sua game matrix. Seguindo os princípios do jogo simples, os resultados serão representados por 1 ou 0 . Aqui haverá uma equivalência entre $\mathrm{V}$ e 1 e entre $\mathrm{F}$ e 0 , sendo que o primeiro par sempre indicará questões de afirmação, e o segundo indicará a negação.

Como estamos em uma atividade de interação - senão estaríamos recaindo no mesmo erro de Shannon e Weaver -, o jogo será de informação imperfeita, indicando simultaneidade nas decisões. Isso condiz com a própria configuração de um "universo" linguístico construído arbitrariamente, mas não intencionalmente.

Assim, só falta saber como os jogadores irão reagir nesse ambiente de informação imperfeita. Vamos pensar em um jogo lógico mínimo, ou seja, com duas letras sentenciais, indicando um jogo com quatro jogadores.

Os jogadores "letras sentenciais" (nesse caso, dois: $p$ e $q$ ) possuem duas opções: existir $(V)$ - representado, em notação lógica, por $p$ e $q$ - ou não existir $(\mathrm{F})$ - representado, em notação lógica, por $\sim p$ e $\sim q$. O jogador "função de verdade" - representado pela letra F possui 16 escolhas, representadas pelo conectivo sentencial de cada função de verdade possível: $\uparrow$ (Tautologia), $\uparrow$ (NOU lógico), (Implicação conversa), つ (Implicação material), V (Disjunção), $\neg$ Q (Negação de Q $), \neg \mathrm{P}$ (Negação de $\mathrm{P}), \oplus$ (Disjunção exclusiva), $\leftrightarrow$ (Bicondicional), P (Proposição P), Q (Proposição Q), $\downarrow$ (NEM lógico), \ (Não implicação material), $\boldsymbol{\Phi}$ (Não implicação conversa), $\boldsymbol{\Lambda}$ (Conjunção) e $\perp$ (Contradição). Por fim, o gatilho V/F - representado pela letra $\mathrm{G}$ - possui duas escolhas, vinculadas ao jogador $\mathrm{F}$ : existir $(\mathrm{V})$ ou não existir $(\mathrm{F})$. 
Os payoffs serão 1 (V), 0 (F) e $\varnothing$ (impossibilidade), sendo válidos para todos os jogadores, ou seja, no limite, quem recebe o payoff é a interação entre esses quatro jogadores. Ou todos vencem (afirmação do jogo de linguagem), ou todos perdem (negação do jogo de linguagem), ou todos caem em um vazio linguístico (impossibilidade satzsistêmica).

Eles serão obtidos através das interações possíveis e que podem ser vistas tanto na tabela de verdade wittgensteiniana como em um diagrama de Venn. Quando há uma interação, o resultado será 1 ou 0. Quando não há interação, graças ao veto do gatilho, o payoff demarcará uma impossibilidade. Dessa forma, com esses dados, conseguimos montar uma game matrix de base para qualquer jogo lógico com duas letras sentenciais:

Matriz-base do jogo lógico com duas letras sentenciais

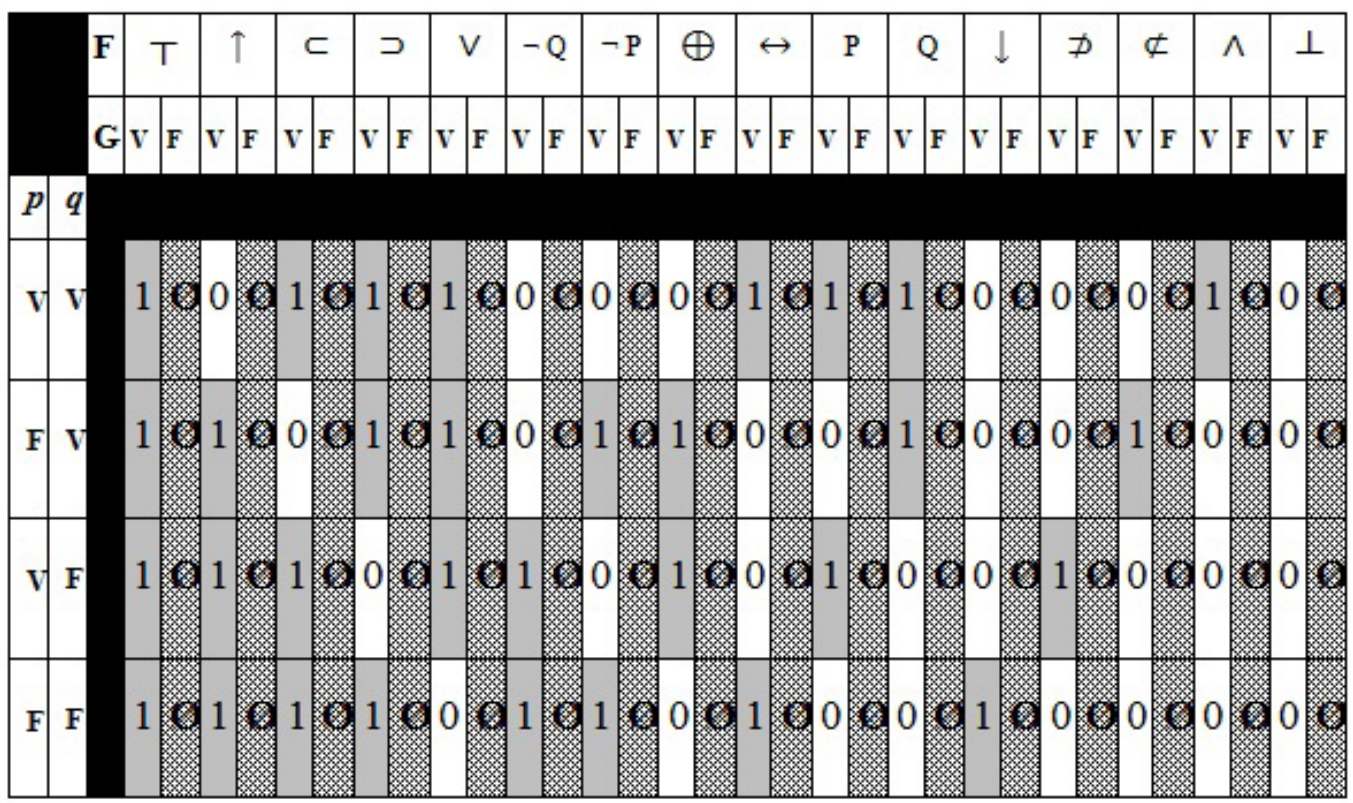

Como é um jogo em que todos vencem ou todos perdem, o jogo lógico de duas letras sentenciais possui 32 payoffs de afirmação (identificados com o número 1 e o sombreamento cinza), 32 payoffs de negação (identificados com o número 0 e a cor branca) e 64 payoffs de impossibilidade (identificados com o $\varnothing$ e o preenchimento rajado em preto e branco). 
No entanto, enquanto todos os payoffs de impossibilidade são idênticos entre si, o mesmo não acontece com os payoffs de afirmação e os de negação. Graças à condição espacial da função de verdade apresentada pelo diagrama de Venn, podemos identificar quatro tipos de payoff de afirmação e quatro tipos de payoff de negação.

Eis aqui a última parte da estrutura do jogo lógico: os payoffs e sua análise por famílias. São dois tipos de família, baseados na Familienähnlichkeit: articulação de letra sentencial e função de verdade.

$\mathrm{Na}$ articulação de letra sentencial, encontramos, no caso de dois jogadores "letra sentencial", quatro famílias: $p q, p \sim q, \sim p q$ e $\sim p \sim q$. Essas quatro famílias são vinculadas aos dois sistemas proposicionais que os jogadores "letra sentencial" representam no modelo comunicacional de Umberto Eco (2007) e suas interações possíveis. Isso, tal como demonstramos, é visto pelos diagramas a seguir. Vamos, primeiramente, ver o posicionamento dos quatro espaços, ou seja, de $p q, \sim p q, p \sim q$ e $\sim p \sim q$ :

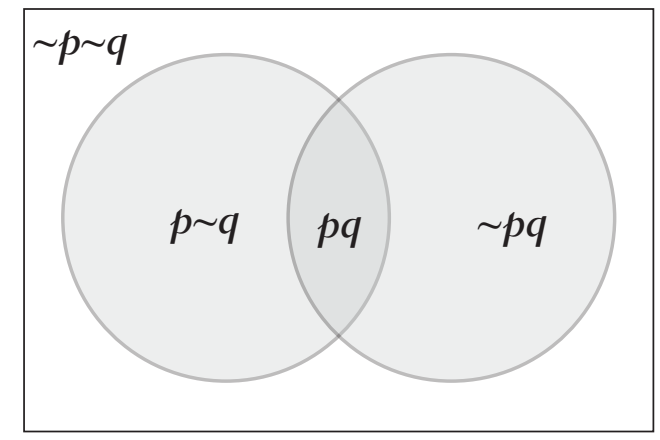

Vemos aqui que $p$ e $q$ estão em uma interação que, nos parece, ao pensarmos em um escopo comunicacional, é semelhante àquela de emissão e recepção. No modelo comunicacional de Umberto Eco (2007, p. 48), um dado interessante de notar é que há ligações entre as partes constituintes da comunicação, porém não há sentido 
definido na maioria delas. A linha principal, uma extensão daquela proposta por Shannon, demonstra uma atividade de interação mútua na significação entre remetente e destinatário.

O caminho aqui é simples e pode ser dividido em quatro grandes grupos: funções do emissor, funções do receptor, interação comunicacional entre emissor e receptor, e comum externo à relação comunicacional. De um mero caminho telegráfico, tal como é visto por Shannon, Eco desenha funções que possuem semelhanças entre si e traçam um multifacetado caminho de interação.

As funções do emissor são: Fonte e Transmissor. São as atividades de pontapé da ação comunicacional. Vincula a questão do recorte do mundo (i.e., fonte) e o motor desse recorte (i.e., transmissor). As funções do receptor são: receptor, fonte e sistema formal, receptor semântico e significação. São todas as funções de consolidação do recorte do mundo, tendo um análogo ao transmissor (i.e., receptor), uma ressignificação do recorte (i.e., fonte) diante da pluralidade de possibilidades (i.e., sistema formal) em que apenas uma será escolhida (i.e., significação) pelo motor do receptor (i.e., receptor semântico). As funções de interação comunicacional entre emissor e receptor são: código de emissão, medium e código de recepção. É a pura intersecção da comunicação em que as duas formas de consolidação enunciativa (i.e., código de emissão e código de recepção) se consolidam em um determinado meio (i.e., medium).

As funções do comum externo à relação comunicacional são: aparatos retóricos, aparatos ideológicos, ruído físico, circunstância e ruído semântico. São todas as situações do espaço e tempo linguísticos que são externos ao processo comunicacional, mas também fazem parte dele. É o pedaço do beweissystem dentro do satzsystem que é o jogo de linguagem.

Assim, é fácil notar que as quatro funções são proposições feitas de proposições que compõem um dado jogo de linguagem. 
Devemos tomar cuidado ao afirmar que essa existência de satzsysteme en abyme montaria um conjunto de proposições. O que é formado aqui não é um conjunto, mas sim um sistema. $\mathrm{O}$ aviso aqui se faz necessário graças às críticas, ao longo do pensamento wittgensteiniano, à falácia que seria a teoria dos conjuntos. Ora, vendo isso, é fácil associar essas quatro funções ao espaço lógico delimitado pelas letras sentenciais. Indicando que $p$ é do emissor e $q$ é do receptor, encontramos a seguinte configuração via diagrama de Venn:

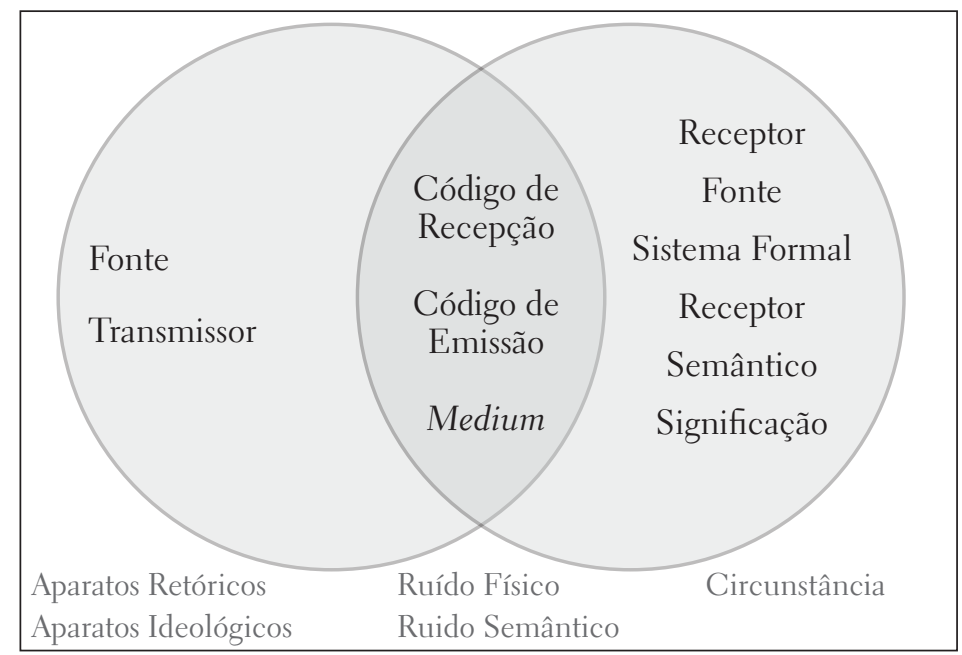

Assim, as funções do emissor são $p \sim q$. As funções do receptor são $\sim p q$. As funções de interação comunicacional entre emissor e receptor são $p q$. Por fim, as funções do comum externo à relação comunicacional são $\sim p \sim q$. Com isso, já podemos analisar os oito payoffs: $1 p q, 1 \sim p q, 1 p \sim q, 1 \sim p \sim q, 0 p q, 0 \sim p q, 0 p \sim q, 0 \sim p \sim q$.

l pq é a obtenção - a afirmação - das funções do receptor de um dado jogo de linguagem e 0 pq é a não obtenção, a negação. De maneira análoga, $1 p \sim q$ e $0 p \sim q$ são, respectivamente, a afirmação e a negação das funções do emissor.

Já na Familienähnlichkeit instaurada pelas funções da verdade, encontramos uma outra configuração. Tal como nos 16 
universos descritos pela lógica semiótica de Christine Ladd, as 16 funções de verdade instauram, entre os seus quatro payoffs, uma Familienähnlichkeit configuracional. Assim, em um jogo lógico com duas letras sentenciais, observamos 16 macroconfigurações de um dado jogo de linguagem comunicacional. Se a família por letra sentencial indica a ênfase dentro do processo comunicacional, a família por função de verdade indica a diferenciação através da articulação dos valores de verdade (que podem ser tanto Verdadeiro como Falso) das diferentes partes do processo comunicacional.

Assim, é traçado um caminho da tautologia à contradição. $\mathrm{Na}$ fileira superior, encontramos a $\mathrm{T}$ (Tautologia), que é a afirmação total. Na segunda fileira, são as funções de verdade que afirmam três de quatro possibilidades de articulação da letra sentencial, a saber: $\uparrow$ (NOU kógico), $\subset$ (Implicação conversa), つ (Implicação material), V (Disjunção). Na terceira fileira, estão as funções que permitem duas afirmações em quatro possibilidades: $\neg$ Q (Negação de Q), ᄀ P (Negação de P), $\oplus$ (Disjunção exclusiva), ↔ (Bicondicional), P (Proposição P) e Q (Proposição Q). Na quarta fileira, são duas afirmações em quatro possibilidades: $\downarrow$ (NEM lógico), \ (Não implicação material), $\boldsymbol{\Phi}$ (Não implicação conversa), $\boldsymbol{\Lambda}$ (Conjunção). E, na quinta fileira, a negação total: $\perp$ (Contradição). Essas duas famílias montam a rede complexa do jogo lógico. Assim, com a normatização dos payoffs em uma tabela relacional entre seus dois agrupamentos de Familienähnlichkeit, encontramos a seguinte representação gráfica: 


\section{Normatização dos payoffs e suas semelhanças familiares}

\begin{tabular}{|c|c|c|c|c|}
\hline Familienähnlichkeit & $p q$ & $p \sim q$ & $\sim p q$ & $\sim p \sim q$ \\
\hline Tautologia $\top$ & $\begin{array}{c}\text { Payoff 1: } \\
1 p q T\end{array}$ & $\begin{array}{c}\text { Payoff 2: } \\
1 p \sim q_{\top}\end{array}$ & $\begin{array}{c}\text { Payoff 3: } \\
1 \sim p q \top\end{array}$ & $\begin{array}{l}\text { Payoff 4: } \\
1 \sim p \sim q T\end{array}$ \\
\hline NOU Lógico $\uparrow$ & $\begin{array}{c}\text { Payoff 5: } \\
0 p q \uparrow\end{array}$ & $\begin{array}{c}\text { Payoff 6: } \\
1 p \sim q \uparrow\end{array}$ & $\begin{array}{c}\text { Payoff } 7: \\
1 \sim p q \uparrow\end{array}$ & $\begin{array}{c}\text { Payoff } 8: \\
1 \sim p \sim q \uparrow\end{array}$ \\
\hline Implicação conversa $\subset$ & $\begin{array}{c}\text { Payoff 9: } \\
1 p q \subset\end{array}$ & $\begin{array}{c}\text { Payoff 10: } \\
1 p \sim q \subset\end{array}$ & $\begin{array}{c}\text { Payoff 11: } \\
0 \sim p q \subset\end{array}$ & $\begin{array}{c}\text { Payoff 12: } \\
1 \sim p \sim q \subset\end{array}$ \\
\hline Implicação material ১ & $\begin{array}{c}\text { Payoff 13: } \\
\text { 1pq }\end{array}$ & $\begin{array}{c}\text { Payoff 14: } \\
0 p \sim q \supset\end{array}$ & $\begin{array}{c}\text { Payoff 15: } \\
1 \sim p q \supset\end{array}$ & $\begin{array}{c}\text { Payoff 16: } \\
1 \sim p \sim q \supset\end{array}$ \\
\hline Disjunção $V$ & $\begin{array}{c}\text { Payoff 17: } \\
1 p q \vee\end{array}$ & $\begin{array}{c}\text { Payoff 18: } \\
1 p \sim q \vee\end{array}$ & $\begin{array}{c}\text { Payoff 19: } \\
1 \sim p q \vee\end{array}$ & $\begin{array}{c}\text { Payoff 20: } \\
0 \sim p \sim q \vee\end{array}$ \\
\hline Negação de $Q \neg Q$ & $\begin{array}{c}\text { Payoff 21: } \\
0 p q \neg \mathrm{Q}\end{array}$ & $\begin{array}{c}\text { Payoff 22: } \\
1 p \sim q \neg Q\end{array}$ & $\begin{array}{c}\text { Payoff 23: } \\
0 \sim p q \neg Q\end{array}$ & $\begin{array}{r}\text { Payoff 24: } \\
1 \sim p \sim q \neg Q\end{array}$ \\
\hline Negação de $\mathrm{P} \neg \mathrm{P}$ & $\begin{array}{c}\text { Payoff 25: } \\
0 p q \neg \mathrm{P}\end{array}$ & $\begin{array}{c}\text { Payoff 26: } \\
0 p \sim q \neg \mathrm{P}\end{array}$ & $\begin{array}{c}\text { Payoff 27: } \\
1 \sim p q \neg \mathrm{P}\end{array}$ & $\begin{array}{l}\text { Payoff 28: } \\
1 \sim p \sim q \neg \mathrm{P}\end{array}$ \\
\hline Disjunção Exclusiva (XOR) $\oplus$ & $\begin{array}{c}\text { Payoff 29: } \\
0 p q \oplus\end{array}$ & $\begin{array}{c}\text { Payoff 30: } \\
1 p \sim q \oplus\end{array}$ & $\begin{array}{c}\text { Payoff } 31: \\
1 \sim p q \oplus\end{array}$ & $\begin{array}{l}\text { Payoff 32: } \\
0 \sim p \sim q \oplus\end{array}$ \\
\hline Bicondicional $\leftrightarrow$ & $\begin{array}{c}\text { Payoff 33: } \\
1 \mathrm{pq} \leftrightarrow\end{array}$ & $\begin{array}{c}\text { Payoff 34: } \\
0 p \sim q \leftrightarrow\end{array}$ & $\begin{array}{c}\text { Payoff } 35: \\
0 \sim p q \leftrightarrow\end{array}$ & $\begin{array}{l}\text { Payoff 36: } \\
1 \sim p \sim q \leftrightarrow\end{array}$ \\
\hline Proposição P P & $\begin{array}{c}\text { Payoff } 37: \\
1 \text { pq } \mathrm{P}\end{array}$ & $\begin{array}{c}\text { Payoff 38: } \\
1 p \sim q \mathrm{P}\end{array}$ & $\begin{array}{c}\text { Payoff 39: } \\
0 \sim p q \mathrm{P}\end{array}$ & $\begin{array}{c}\text { Payoff 40: } \\
0 \sim p \sim q \mathrm{P}\end{array}$ \\
\hline Proposição Q Q & $\begin{array}{c}\text { Payoff 41: } \\
1 \text { pqQ }\end{array}$ & $\begin{array}{c}\text { Payoff 42: } \\
0 p \sim q \mathrm{Q}\end{array}$ & $\begin{array}{c}\text { Payoff 43: } \\
1 \sim p q \mathrm{Q}\end{array}$ & $\begin{array}{c}\text { Payoff 44: } \\
0 \sim p \sim q \mathrm{Q}\end{array}$ \\
\hline NEM Lógico $\downarrow$ & $\begin{array}{c}\text { Payoff 45: } \\
0 p q \downarrow\end{array}$ & $\begin{array}{c}\text { Payoff 46: } \\
0 p \sim q \downarrow\end{array}$ & $\begin{array}{c}\text { Payoff 47: } \\
0 \sim p q \downarrow\end{array}$ & $\begin{array}{c}\text { Payoff 48: } \\
1 \sim p \sim q \downarrow\end{array}$ \\
\hline 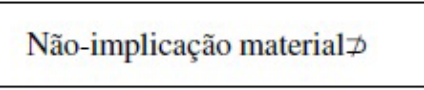 & $\begin{array}{c}\text { Payoff 49: } \\
0 p q \not \supset\end{array}$ & $\begin{array}{c}\text { Payoff 50: } \\
1 p \sim q \not \supset\end{array}$ & $\begin{array}{c}\text { Payoff 51: } \\
0 \sim p q \not D\end{array}$ & $\begin{array}{c}\text { Payoff 52: } \\
0 \sim p \sim q \not D\end{array}$ \\
\hline Não-implicação conversa $\not \subset$ & $\begin{array}{c}\text { Payoff 53: } \\
0 p q \not \subset\end{array}$ & $\begin{array}{c}\text { Payoff 54: } \\
0 p \sim q \not \subset\end{array}$ & $\begin{array}{c}\text { Payoff 55: } \\
1 \sim p q \not \subset\end{array}$ & $\begin{array}{c}\text { Payoff 56: } \\
0 \sim p \sim q \not \subset\end{array}$ \\
\hline Conjunção $\wedge$ & $\begin{array}{c}\text { Payoff 57: } \\
\text { 1pq^ }\end{array}$ & $\begin{array}{c}\text { Payoff 58: } \\
0 p \sim q \wedge\end{array}$ & $\begin{array}{c}\text { Payoff 59: } \\
0 \sim p q \wedge\end{array}$ & $\begin{array}{c}\text { Payoff 60: } \\
0 \sim p \sim q \wedge\end{array}$ \\
\hline Contradição $\perp$ & $\begin{array}{c}\text { Payoff 61: } \\
0 p q \perp\end{array}$ & $\begin{array}{c}\text { Payoff 62: } \\
0 p \sim q \perp\end{array}$ & $\begin{array}{c}\text { Payoff 63: } \\
0 \sim p q \perp\end{array}$ & $\begin{array}{c}\text { Payoff 64: } \\
0 \sim p \sim q \perp\end{array}$ \\
\hline
\end{tabular}

Com isso, se o estudo do parergon é um estudo lógico, o estudo do ergon (diferendos) é um estudo pragmático. Podemos dizer, então, que a distinção entre diferendos de um mesmo jogo de linguagem está na avaliação dos diferenciais da sua performatividade. Determinar um diferendo em relação ao seu jogo de linguagem é, nada mais nada menos, do que analisar o seu modo de operação através dos índices diferenciais (i.e., palavras-chave) ilocucionários. 
Dessa forma, para cada diferença posta por Searle, devemos traçar parâmetros de análise que levem em conta a multiplicidade sentencial de um diferendo. Além disso, não se pode esquecer que a composição desses gêneros do discurso tem que estar coerente ao campo comunicacional, que, no limite, é a articulação última entre linguagem e mundo.

Determinamos aqui, então, 12 dimensões (SEARLE, 2002, p. 2-11) que compõem o diferendo e suas sentenças que, em sua multiplicidade, estão em disputa, como bem coloca Lyotard com a sua noção de agonismo da linguagem: propósito ilocucionário, direção do ajuste, condição de sinceridade, ênfase, posicionalidade, interesse, contexto circundante, temporalidade, necessidade, institucionalização extralinguística (competência), função verbal e estilo.

Um gênero do discurso só pode ser considerado enquanto tal se estiver em referência a essas 12 dimensões. A não demarcação de uma delas, por exemplo, poderá causar um campo de indiferenciação do ergon e, com isso, por exemplo, esconder nuances da ação linguística que podem ser importantes para uma melhor compreensão de uma determinada linguagem.

Lógica e pragmática não entram aqui enquanto concorrentes, mas sim enquanto parceiras analíticas na definição e no estudo de uma linguagem. Enquanto a primeira analisa os modos de recorte, a segunda analisa a ação possibilitada pelo recorte.

\section{A gramática do rádio}

Com a metodologia descrita pela seção anterior, é possível construir a gramática do rádio, baseada na análise da cena radiofônica da região metropolitana de São Paulo, representada por um corpus de múltiplos composto por dois tipos de coleta: uma de programas radiofônicos e outra de grades de programação. A primeira abrangeu metade do dial paulistano e para a segunda foram coletadas grades de programação de todas emissoras AM e FM de São Paulo-SP (e arredores) do período 2011-2012. 
Assim, foi possível montar, analisando parergon e ergon, uma gramática do rádio com dois sistemas proposicionais, quatro ênfases comunicacionais, sete diferendos/gêneros do discurso e 65 configurações do jogo de linguagem do rádio.

Os dois sistemas demarcam o caminho proposicional radiofônico. Se, por um lado, a existencialidade do som radiofônico, ocupante do sistema proposicional sonoro do rádio (o $p$ do rádio), se concentra em um caráter "maquínico", seja pela mecânica de suas ondas, seja pelas máquinas que o tornam possível, o sistema proposicional auditivo, o $q$ do rádio, é baseado na capacidade humana de ouvir. Tal como as máquinas do som radiofônico proporcionam um recorte, a audição humana também proporciona um recorte que vai desde os limites da audição humana aos mecanismos de (re) presentação e de reconhecimento que a linguagem auditiva proporciona autonomamente.

As quatro ênfases mostram as articulações entre os sistemas proposicionais. Quando há obtenção dos dois $(p q)$, há a montagem radiofônica. Montagem essa que é do poderio da mente, intrínseca da relação linguagem-mundo, que representa a necessidade lógica que está na junção radiofônica de uma estrutura "maquínica" sonora específica com um recorte de significação realizado pela audição humana. Quando há domínio apenas do som $(p \sim q)$, há o campo que podemos denominar de plástica radiofônica. Ele é composto, ordinariamente, pelas ideias de sonoplastia para rádio. Ideias essas que estão vinculadas a uma série de usos da voz humana, da música, dos efeitos sonoros e do silêncio, que são notados por qualquer um que teve mesmo um leve contato com a prática midiática radiofônica.

Quando há predomínio da audição $(\sim p q)$, temos a ênfase da escuta radiofônica. Temos aqui, dessa forma, uma atitude afirmativa do receptor em um reconhecimento/compreensão do protocolo comunicacional que é realizado nessa prática midiática que chamamos de rádio. É um rádio que existe na ausência do aparelho, nos emaranhados dos sense-datas auditivos que a nossa mente proporciona ao se pôr na interação entre linguagem e mundo. 
Por fim, a articulação $\sim p \sim q$ (a ênfase antirradiofônica) significa o descrédito tanto daquilo que é do sistema proposicional sonoro como daquilo que faz parte do sistema proposicional auditivo do jogo de linguagem radiofônico. Dentro da concepção do modelo comunicacional de Eco, isso significa um domínio das funções do comum externo à relação comunicacional. Ora, se a interação $(p q)$ é aquela que é focada nos estudos por uma ontologia do rádio, o comum exterior $(\sim p \sim q)$ é o grande escolhido para aqueles estudos que buscam a análise da presença concreta do rádio. São trabalhos sobre ideologia, discurso, usos da língua, história, biografias, entre outras.

Único membro do ergon e de sua pragmática, os sete diferendos são os gêneros do discurso radiofônico, base da produção dos programas de rádio, das formas de agir com a linguagem radiofônica. No estudo, encontramos sete ativas em uma cena ampla do rádio metropolitano AM-FM de São Paulo: os cinco diferendos que fizeram parte do corpus de coleta - a saber: jornalístico, esportivo, musical, humorístico e de variedades - mais o gênero ficcional (tradicional em rádio, mas pouco presente na cena paulistana) e o onipresente gênero publicitário.

Por fim, essas 65 configurações montam, quando aplicadas ao rádio, o satzsystem da linguagem radiofônica. Cada configuração está articulada dentro de uma ênfase, colocando, dessa maneira, o satzsystem enquanto a régua do jogo de linguagem do rádio. É essa régua que permite entendermos a nossa vivência desse jogo de linguagem comunicacional que resulta em uma prática midiática. Assim, para fazer parte da linguagem radiofônica, do seu recorte, precisamos ter tal régua contra a realidade resultante da interação entre linguagem e mundo. Com isso, participamos de todas as configurações radiofônicas.

No entanto, simultaneamente, vivenciamos só uma. Essa vivência de uma é porque sabemos, através da régua satzsistêmica, que é dessa uma que estamos diante e que não estamos diante de nenhuma das outras. Assim, a simultaneidade se resume a saber, ao mesmo tempo, que ouvimos uma e que não ouvimos todas as outras. 
Podemos afirmar, então, que rádio é uma linguagem que permite a articulação de um som próprio, denominado som radiofônico, com a audição humana e que, com isso, se configura apto para um uso midiático (i.e., de comunicação social), visando a legitimação da fala e da escuta enquanto meios autônomos dotados de técnica "maquínica" e configuração linguística própria - de comunicação em escala social.

A isso podemos acrescentar que rádio faz parte do amplo escopo de linguagens midiáticas que são unidas por um ar familiar [Familienähnlichkeit] e que tais linguagens possuem inter-relações proposicionais, constituindo um satzsystem próprio. Tal satzsystem consolida a condição das práticas midiáticas e demarca a (re) presentação delas enquanto linguagem, permitindo a distinção de cada prática midiática (i.e., cada jogo de linguagem midiático) dos demais fatos do mundo.

É assim que se torna possível construir uma gramática do rádio. A garantia de distinção do rádio diante do mundo está simplesmente no seu jogo de linguagem, em seu satzsystem en abyme, sua condição enquanto linguagem aqui demonstrada. 


\section{Referências}

BAKER, G. P; HACKER, P. M. S. Wittgenstein: understanding and meaning (Part II: Exegesis \\1-184). Malden: Blackwell, 2005.

DERRIDA, J. Dissemination. Chicago: University of Chicago Press, 1981.

The truth in painting. Chicago: University of Chicago

Press, 1987.

ECO, U. A estrutura ausente. São Paulo: Perspectiva, 2007.

FERRO, R. Estrutura y desconstrucción. Buenos Aires: Biblos, 1992.

GOMES, M. R. Repetição e diferença nas reflexões sobre comunicação. São Paulo: Annablume, 2001.

KANT, I. Critique of judgment. Mineola: Dover, 2005.

LYOTARD, J.-F. The differend. Minneapolis: UMP, 2007.

SEARLE, J. R. Expressão e significado. São Paulo: Martins Fontes, 2002.

SHANKER, S. G. Wittgenstein and the turning-point in the philosophy of mathematics. Albany: Suny, 1987.

SOWA, J. F. "The role of logic and ontology in language and reasoning" (preprint article do capítulo 11 de POLI, R.; SEIBT, J. (Org.). Theory and applications of ontology), 2010. Disponível em: <http://www.jfsowa.com/pubs/rolelog.pdf>.

WITTGENSTEIN, L. Fichas (Zettel). Lisboa: Edições 70, 1989. . Investigações filosóficas. São Paulo: Nova Cultural, 1999. . Tractatus logico-philosophicus. New York: Harper, 2009. 